\title{
Effects of ACTH and Adrenocortical Hormones on the Glyconeogenesis in Liver and Muscle of Normal and Alloxan Diabetic Rabbits

\author{
KENZO W AKABAYASHI
}

Department of Internal Medicine, Division II, Kobe Medical College (Director, Prof. M. Takeda)

Much have been studied on the relationship between the pituitary and adrenocortical hormones and the metabolism of carbohydrate in normal and alloxan diabetic animals, however, as far as the effects of these hormones on the glycogen formation in liver and muscle have been reported with the varying results. Hence, the present experiments were designed to determine what changes might have occurred in the carbohydrate figures in both livers and muscles upon a single injection or by the prolonged administration of these hormones (daily injection of the hormones for 7 days) to the normal and the alloxan diabetic rabbits.

In order to compare the action of insulin with these hormones, the effects of insulin upon the carbohydrate figures in liver and muscle have been studied and estimated simultaneously. As to the method of determination of carbohydrate figures in liver and muscle, the method reported previously by Yamamoto from this laboratory in 1940 was followed by having the rabbits injected with these hormones and then the slices of tissues from the livers and muscles were removed before and after the administration from the same animals: and the total carbohydrate, free and hydrolysable sugar and glycogen contents were estimated.

The following results have been obtained and summarized:

1. With the carbohydrate figures of liver in normal and alloxan diabetic rabbits, five hours after the single injection of the hormones, DOCA injected rabbits showed the definite finding of marked depletion of the total carbohydrat and glycogen contents, while, with the cortisone and ACTH injected rabbits, there was slight increase in the glycogen content, but no changes were seen in thetotal carbohydrate.

2. In the glycogen formation of muscle by normal and alloxan diabetic rabbits following five hours after the injection of hormones, there were slight glycogenolytic effect shown with DOCA and cortisone, but the slight glycogenic effect was demonstrated with the insulin and ACTH.

3. It is of interest to note that DOGA shows the insulin effect for the blood sugar of alloxan diabetic rabbits, and the contrainsulin effect for the glycogen formation in liver and muscle of normal and alloxan diabetic rabbits.

4. Following seven days' injection of the hormones, there were seen the significant rises of glycogen value in liver by cortisone or insulin injected normal and alloxan diabetic rabbits, however, no definite changes were observed with ACTH or DOGA injection. 


\title{
下垂体前葉, 副婜皮質系ホルモンの肝並に 筋糖原造成作用に関する実験的研究
}

\author{
神戸熙科大学第二内科学教空 (指導 竹田正次教摇)
}

若林健 三

\section{I 緒言}

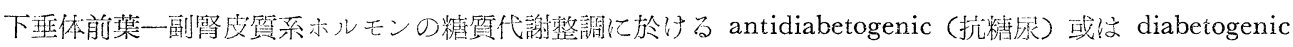

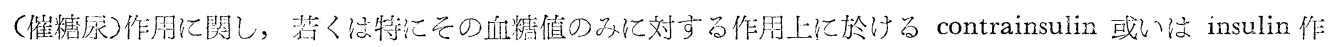

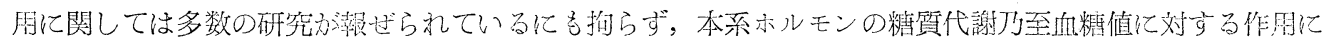
関しては未だ明磪な判定か下されていない.

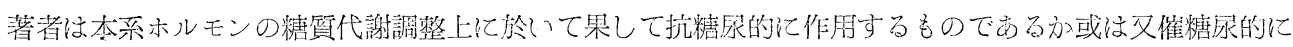

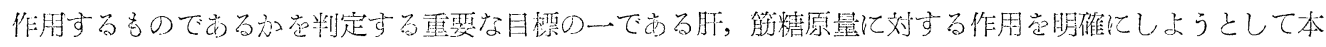
研究寺企図した次第である。

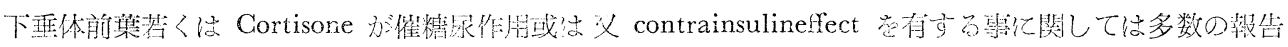

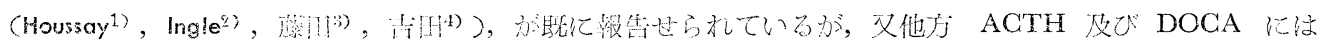

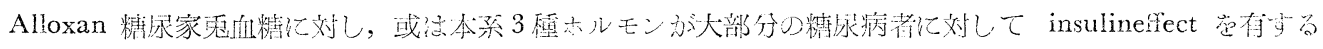

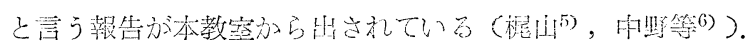

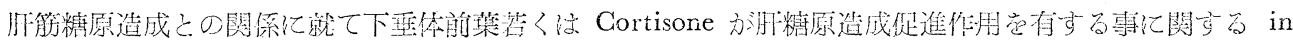

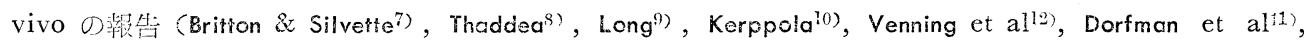

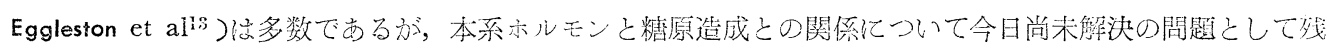
されているのは次の諸項で㟧らうと思われる。

1. DOCA の glycogenesis 或は glyconeogenesis 亿就ては定説がない. 即ち, DOCA 飞も glycogenesic の作用があると言う人 (Gration \& Jensen ${ }^{14)}$, Verzar et a al ${ }^{15)}$ ) とをれに反対する人々 (Ingle ${ }^{16)}$ )とがある.

2. 本系ホルモン中 ACTH 及び cortisone と朋糖原造成作用之の闇の関係に就てに大体に於て從来の研

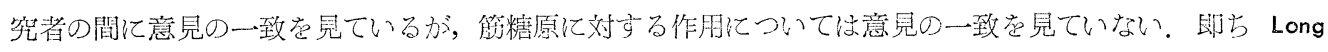

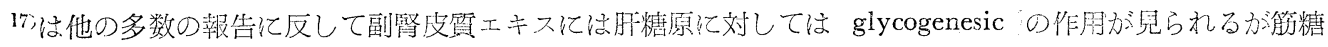

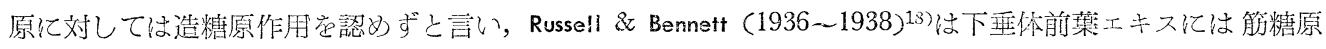

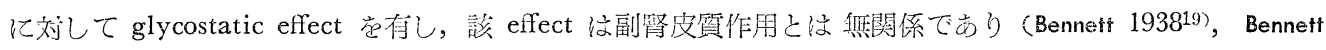
\& Perkins 194507), 最近 growth ホルモンと該作用があると Russell \& Willhelm:21), Milman \& Russell(22) 亿 上つて報告せられている。即ち本系ホルモンは䍐と筋糖原とに対して, 後者は造糖的に, 前者解原的に作 用すると言うのである。

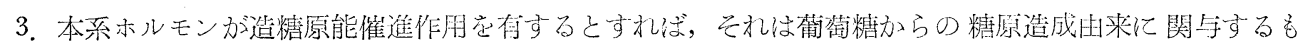

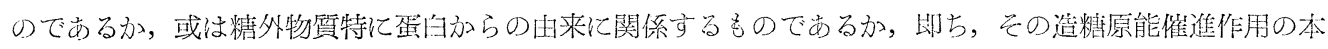
質についてである. 蛋白由来の糖原に対する副腎皮質示ルモンの作用については Long et al. 1950²3)，Engel

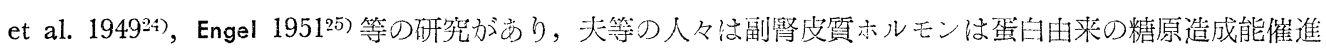
作用を有すると言つている。

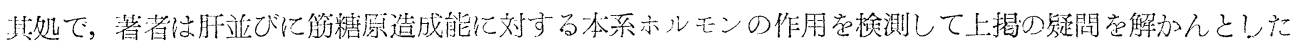

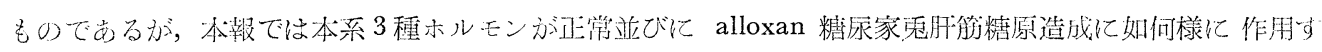

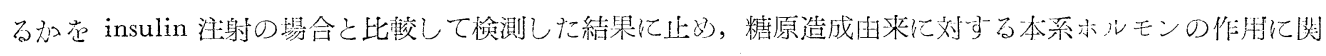

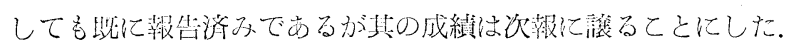




\section{II 実 験方法}

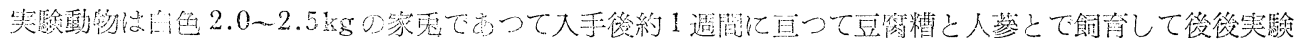

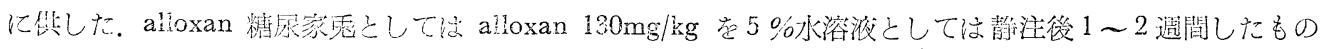

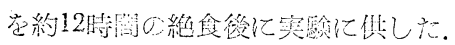

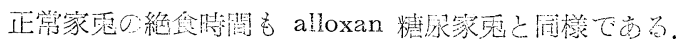

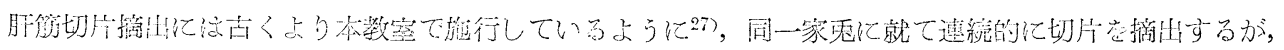

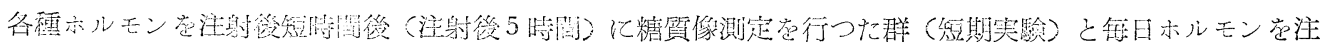

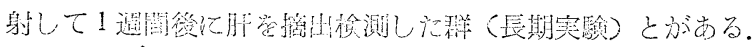

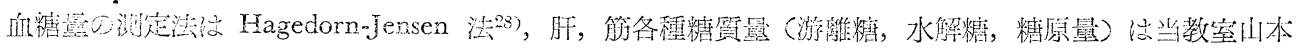

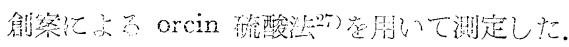

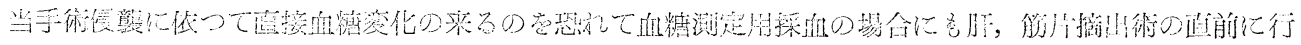
$2+5$.

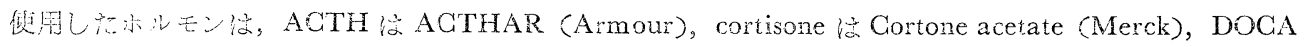
W Syncoria (武泪), insulin

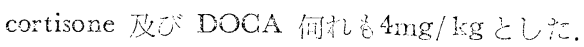

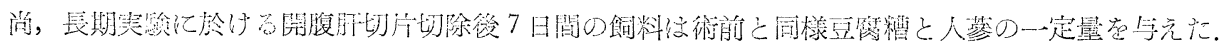

\section{III 实 験 成 縝}

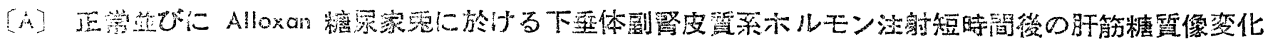

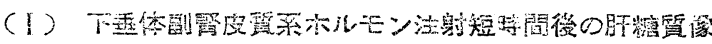

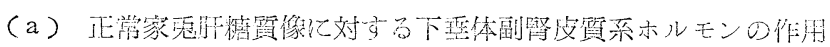

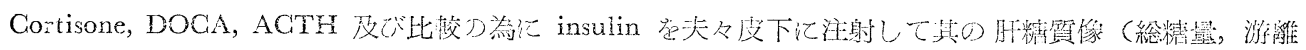

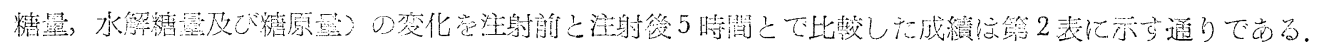

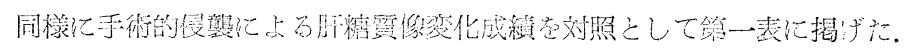

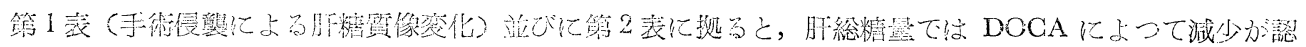

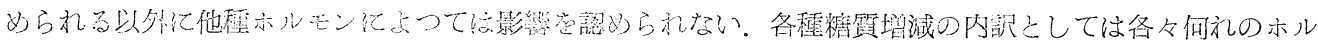

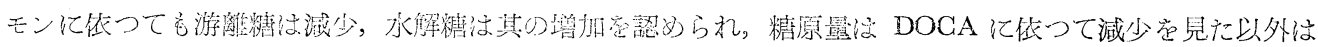

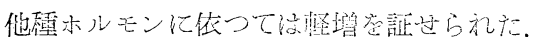

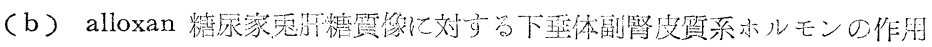

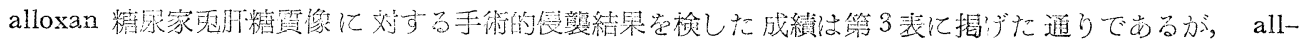

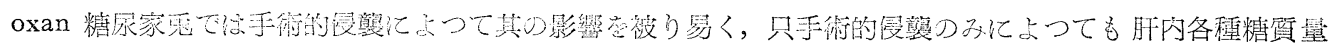

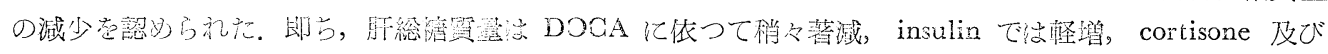

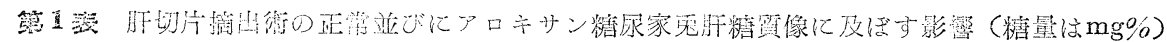

\begin{tabular}{|c|c|c|c|c|c|c|}
\hline & \multicolumn{3}{|c|}{ 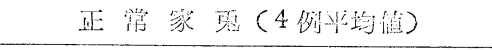 } & \multicolumn{3}{|c|}{ 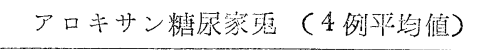 } \\
\hline & \multirow{2}{*}{ 前! } & \multicolumn{2}{|r|}{$5^{\circ}$} & \multirow{2}{*}{ 前 } & \multicolumn{2}{|c|}{$5^{\circ}$} \\
\hline & & & 䁌減譬 $(\%)$ & & & 增減率 $(\%)$ \\
\hline 総 梼 至 & $3514 \pm 298$ & $3330 \pm 324$ & $-5.2 \pm 1.2$ & $1933 \pm 231$ & $1550 \pm 284$ & $-20.0 \pm 1.1$ \\
\hline 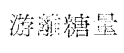 & $1015 \pm 30$ & $1099 \div 282$ & $+8.3 \pm 1.0$ & $773 \pm 136$ & $574 \pm 143$ & $-26.3 \pm 9.0$ \\
\hline 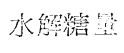 & $903 \pm 28$ & $770 \pm 49$ & $-14.7 \pm 4.7$ & $581 \pm 20$ & $492 \pm 19$ & $-15.3 \pm 1.2$ \\
\hline 䊮原将 & $1596 \pm 291$ & $1461 \pm 208$ & $-3.5 \pm 3.5$ & $575 \pm 91$ & $484 \pm 56$ & $-15.8 \pm 4.4$ \\
\hline 抓糖琵 & $107 \pm 7$ & $133 \pm 12$ & $+24.3 \pm 5.5$ & $287 \pm 12$ & $332 \pm 22$ & $+15.7 \pm 3.2$ \\
\hline
\end{tabular}


ACTH では変化を認められなかつた。

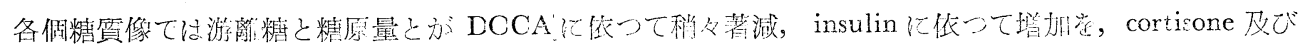
ACTHによつて微增虑認められた。

第 2 表 cortisone, DCA, ACTH 及び insulin

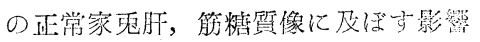
(糖量络 $\mathrm{mg} \%$ )

\begin{tabular}{|c|c|c|c|c|}
\hline \multirow{2}{*}{$\begin{array}{l}\text { 例数 } \\
\text { 文処 } \\
\text { 罱別 }\end{array}$} & & & \multicolumn{2}{|r|}{$5^{\circ}$} \\
\hline & & & & 增減率 $(0)$ \\
\hline 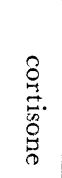 & 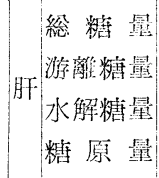 & $\begin{array}{r}3977 \pm 414 \\
1133 \pm 165 \\
798 \pm 105 \\
2025 \pm 429\end{array}$ & $\begin{array}{r}3699 \pm 403 \\
941 \pm 119 \\
688 \pm 119 \\
2070 \pm 461\end{array}$ & $\begin{array}{r}-6.9 \pm 3.7 \\
-17.0 \pm 11.3 \\
-13.3 \pm 5.1 \\
+2.2 \pm 2.3\end{array}$ \\
\hline $\begin{array}{l}\text { 志 } \\
\text { 例 } \\
\text { 均 }\end{array}$ & 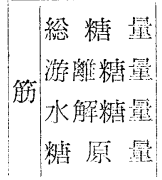 & $\begin{array}{r}1479 \pm 108 \\
531=52 \\
414 \pm 32 \\
535 \pm 33\end{array}$ & $\begin{array}{r}1306 \pm 127 \\
464 \pm 90 \\
321 \pm 62 \\
521 \pm 25\end{array}$ & $\begin{array}{l}-11.7 \pm 4.6 \\
-12.6 \pm 10.2 \\
-22.5 \pm 14.6 \\
-2.6 \pm 1.4\end{array}$ \\
\hline $\begin{array}{l}\forall \\
\Omega \\
D\end{array}$ & 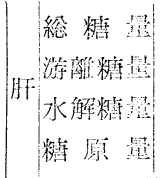 & $\begin{array}{r}2857 \pm 306 \\
641 \pm 259 \\
850 \pm 64 \\
1367 \pm 301\end{array}$ & $\begin{array}{r}2282 \pm 324 \\
513 \pm 229 \\
767 \pm 7 \\
1002 \pm 166\end{array}$ & $\begin{array}{l}-20.1 \pm 7.3 \\
-20.0 \pm 9.1 \\
-9.7 \pm 5.8 \\
-26.7 \pm 4.2\end{array}$ \\
\hline $\begin{array}{l}\text { 例 } \\
\text { 留 } \\
\text { 均 }\end{array}$ & 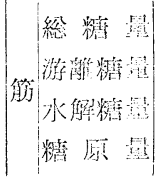 & $\begin{array}{r}1172 \pm 144 \\
396 \pm 25 \\
350 \pm 45 \\
426 \pm 36\end{array}$ & $\begin{array}{r}1040 \pm 158 \\
336 \pm 34 \\
293 \pm 41 \\
406 \pm 35\end{array}$ & $\begin{array}{l}-11.3 \pm 3.8 \\
-15.2 \pm 3.4 \\
-14.8 \pm 1.5 \\
-4.7 \pm 0.1\end{array}$ \\
\hline 承 & 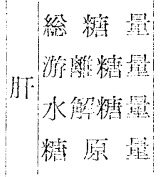 & $\begin{array}{r}2381 \pm 304 \\
690 \pm 76 \\
544 \pm 67 \\
1147 \pm 72\end{array}$ & $\begin{array}{r}2255 \pm 311 \\
483 \pm 32 \\
576 \pm 82 \\
1196 \pm 37\end{array}$ & $\begin{array}{l}-5.3 \pm 3.3 \\
-30.0 \pm 5.6 \\
+5.9 \pm 24.6 \\
+4.3 \pm 9.5\end{array}$ \\
\hline $\begin{array}{l}\because \\
\text { 例 } \\
y \\
y \\
1\end{array}$ & 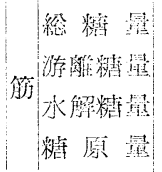 & $\begin{array}{r}1270 \pm 134 \\
388 \pm 47 \\
317 \pm 49 \\
565 \pm 30\end{array}$ & $\begin{array}{r}1227 \pm 153 \\
442 \pm 99 \\
281 \pm 48 \\
504 \pm 79\end{array}$ & $\begin{array}{l}-3.4 \pm 2.5 \\
+13.9 \pm 21.3 \\
-11.4 \pm 15.7 \\
-10.8 \pm 4.1\end{array}$ \\
\hline 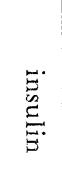 & 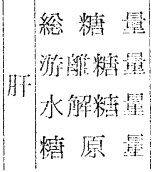 & $\begin{array}{r}2282 \pm 387 \\
1376 \pm 121 \\
798 \pm 103 \\
1108 \pm 14\end{array}$ & $\begin{array}{r}3084 \pm 374 \\
1048 \pm 464 \\
847 \pm 120 \\
1189 \pm 102\end{array}$ & $\begin{array}{r}-6.0 \pm 3.1 \\
-16.6 \pm 12.4 \\
+6.1 \pm 7.3 \\
+7.3 \pm 7.1\end{array}$ \\
\hline $\begin{array}{l}\text { 例 } \\
\text { 平 } \\
\text { 均 }\end{array}$ & 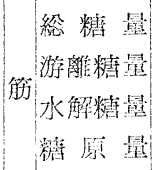 & $\begin{array}{r}1622 \pm 86 \\
671 \pm 46 \\
440 \pm 33 \\
511 \pm 35\end{array}$ & $\begin{array}{r}1532 \pm 73 \\
575 \pm 48 \\
484 \pm 32 \\
473 \pm 53\end{array}$ & $\begin{array}{r}-5.5 \pm 2.2 \\
-14.3 \div 12.4 \\
+10 . \pm 0.1 \\
-7.4 \leq 2.8\end{array}$ \\
\hline
\end{tabular}

管 3 空 cortisone, DCA, ACTH 及び insulin

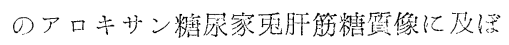

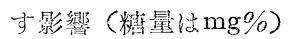

\begin{tabular}{|c|c|c|}
\hline 迈例 & & $5^{\circ}$ \\
\hline$j$ & [Hi] & 增減渠 $(\%)$ \\
\hline
\end{tabular}

総 樣 聂 $1842 \pm 2041548 \pm 228-16.0 \pm 3.4$

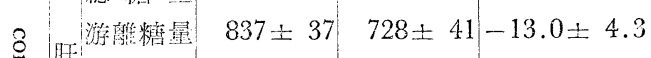

总. 肝水解糖暴 $582 \pm 74 \quad 412 \pm 62-29.2 \pm 12.3$

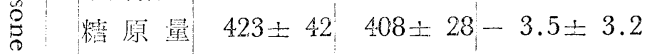

三 総 糖显 $1131 \pm 167 \quad 691 \pm 104-39.0 \pm 11.1$

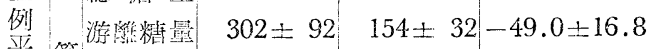

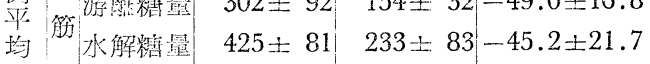

䊒原舅 $404 \pm 66 \quad 304 \pm 34-24.7 \pm 14.0$

総 精 畕 $2973 \pm 2861476 \pm 276-50.4 \pm 15.7$

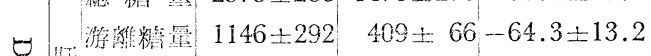

8 水解㮖星 $866 \pm 155625 \pm 52-27.8 \pm 11.1$

$>$ 筑原量 $961 \pm 285 \quad 442 \pm 228-54.0 \pm 12.4$

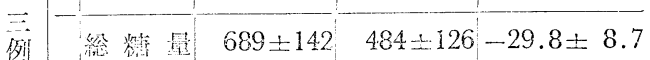

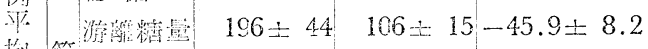

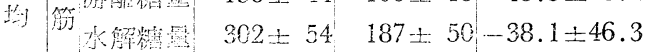

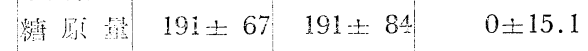

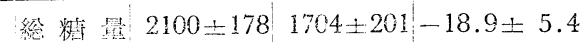

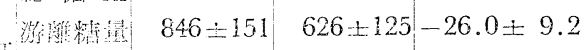

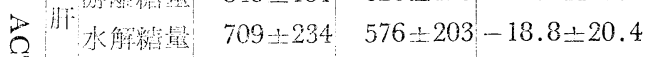

粹原㤠 $545 \pm 154 \quad 502 \pm 226-7.9 \pm 6.9$

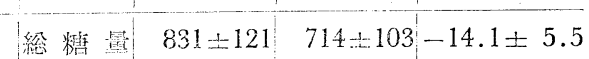

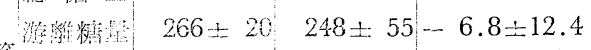

篎长解粮鼠 $310 \pm 16 \quad 225 \pm 98-27.4 \pm 11.4$

粒原 $255 \pm 83 \quad 241 \pm 148-5.5 \pm 27.6$

総糖舅 $1706 \pm 204 \quad 1637 \pm 197 \mid-4.0 \pm 2.4$

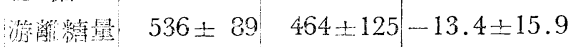

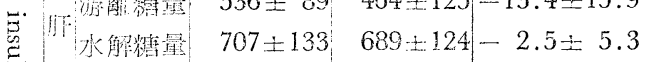

鹤原鼠 $463 \pm 104 \quad 484 \pm 182-4.5 \pm 12.6$

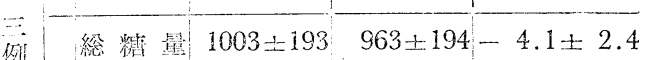

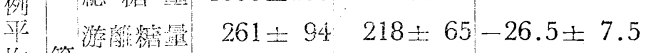

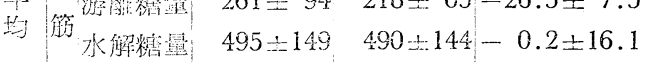

粼原量 $247 \pm 46 \quad 251 \pm 40+1.6 \pm 7.2$ 


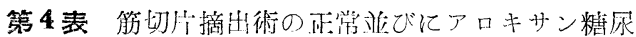

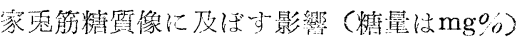

\begin{tabular}{|c|c|c|c|c|c|c|}
\hline & \multicolumn{3}{|c|}{ 正 渻 家 元 } & \multicolumn{3}{|c|}{ 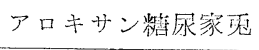 } \\
\hline & 前 & $5^{\circ}$ & 增減率 & 前 & $5^{\circ}$ & 増娍沎 \\
\hline 総糖量 & 1396 & 1273 & -8.8 & 549 & 448 & -10 \\
\hline 游離糖量 & 440 & 372 & -15.5 & 216 & 167 & -22.2 \\
\hline 水解糖量 & 396 & 360 & -9.1 & 127 & 100 & -21.0 \\
\hline 糖 原量 & 560 & 541 & -3.4 & 206 & 181 & -12.1 \\
\hline 血糖量 & 100 & 122 & +22 & 280 & $3 C 6$ & +9.3 \\
\hline
\end{tabular}

\section{[II]下垂体副腎皮質ホルモン注射短時 間後の筋糖質像変化}

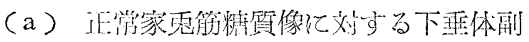

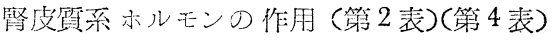
各稫ホルモン注射に依る筋糖質像変化は軽 度であつて，総糖質量では cortisone と DOGA に依つて軽減总見た以外に ACTH 及び insulin に依つては対照家鬼（手術的侵 部家蒐) に比して其の減少か軽度であつたか ら，雨ホルモンによつては寧ろ軽增を見た結 罢になる。各個糖質像の変化も軽度であつて

各種ホルモン注射による特異像であるかどうか子判定し得ない程度であつた。

(b) alloxan 糖尿家鬼筋糖質像と対する下垂体副婜皮質系ホルモンの作用

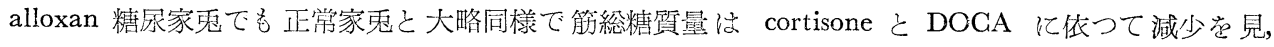
ACTHによつて微減，insulinによつては対照家鬼より軽増を晃た。各個糖質像では DOCA 並びに cortisone に依つては各個糖質は全部減少走呈して々る。 又 insulin によつては筋游離糖の減少を認められる。

要するに以上の正常立びそ alloxan 糖尿家鬼筋糖質像に刘する各橿ホルモンの影響結果加ら見ると，筋 糖檳に対して cortisone と DOAA とには glycogenolytic の作用を，insulin 及び ACTH には軽微の glycogenesic の作用があるものと認められる。

\section{[鬥]下垂体副監皮質系ホルモン注射短時間後の血糖像(第 5 図).}

第 5 表 肝切片摘出手術(対照)及び各種ホルモン 注射の正常並びにアロキサン糖尿家鬼面

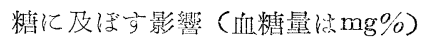

\begin{tabular}{|c|c|c|c|c|c|}
\hline & \multirow{2}{*}{ 処 置 別 } & \multirow{2}{*}{$\begin{array}{l}\text { 例 } \\
\text { 数 }\end{array}$} & \multirow{2}{*}{ 前 } & \multicolumn{2}{|r|}{$5^{\circ}$} \\
\hline & & & & & 増娍茲 \% \\
\hline \multirow{5}{*}{$\begin{array}{l}\text { 正 } \\
\text { 常 } \\
\text { 家 } \\
\text { 鬼 }\end{array}$} & 対 & 4 & $107 \pm 7$ & $133 \pm 12$ & $+24.3 \pm 5.5$ \\
\hline & cortisone & 3 & $105 \pm 7$ & $186 \pm 36$ & $+77.1 \pm 33.1$ \\
\hline & DOCA & 3 & $113 \pm 11$ & $125 \pm 12$ & $+10.6 \pm 0.5$ \\
\hline & ACTH & 3 & $105 \pm 11$ & $163 \pm 27$ & $+55.2 \pm 12.0$ \\
\hline & insulin & 3 & $104 \pm 0$ & $75 \pm 18$ & $-27.9 \pm 15.4$ \\
\hline \multirow{5}{*}{$\begin{array}{l}\text { ア } \\
\text { 糖 } \\
\text { 丞 } \\
\text { 框 }\end{array}$} & & 4 & $287 \pm 12$ & $332 \pm 22$ & $+15.7 \pm 3.2$ \\
\hline & cortisone & 3 & $34^{\prime} \pm \pm 38$ & $324 \pm 13$ & $-6.1 \pm 1.5$ \\
\hline & DOCA & 3 & $283 \pm 36$ & $194 \pm 31$ & $-31.4 \pm 1.5$ \\
\hline & ACTH & 3 & $317 \pm 27$ & $267 \pm 35$ & $-15.8 \pm 7.9$ \\
\hline & insulin & 3 & $335 \pm 54$ & $305 \pm 56$ & $-9 . \pm 2.8$ \\
\hline
\end{tabular}

正常家鬼では cortisone と ACTH とに 上つては血糖は上昇，DOCA とよつては 殆んど変化なく， insulin 亿依つては下降。 息た。

alloxan 糖尿家鬼では备種示ルモン其の 何れによつてき血糖の下降を芫，特に DOCA 並びに insulin(注射捘 5 時間)に依 つては稍々藷減定見だ

但し，本成績で忧 alloxan 糖尿家鬼て 於ける各種示ルモンの降血糖度は從来の趐

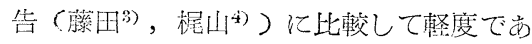

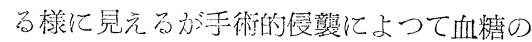
上舁定見ののであるふら本成績では其の手

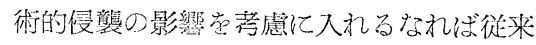
の報告(藤四，暒山）之大同小異である。 今血糖変化像亡朋並びそ筋糖䫓像变化と 定相刘比して見ろのに，其の血桾变化方最

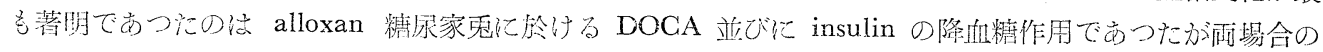

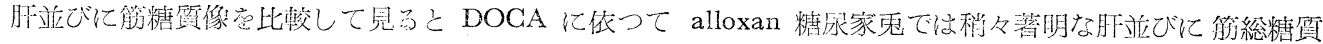

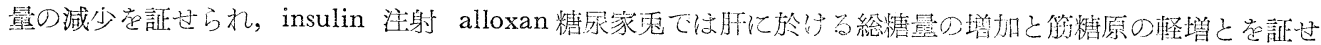

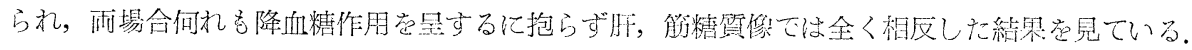

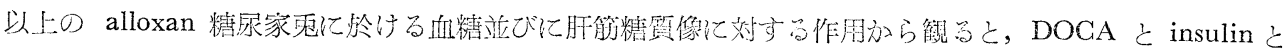

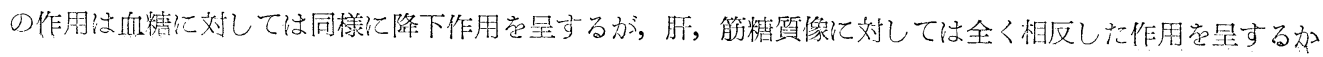


第 6 表 無処置, cortisone, LCCA, ACTH 及び insulin 7 日間注射の正党家无肝糖質像に及ぼす影留 (梼最拄 $\mathrm{mg} \%$ )

\begin{tabular}{|c|c|c|c|c|c|}
\hline \multirow{2}{*}{$\begin{array}{l}\text { 処 } \\
\text { 监 } \\
\text { 別 }\end{array}$} & \multirow{2}{*}{$\begin{array}{l}\text { 例 } \\
\text { 数 }\end{array}$} & & \multirow{2}{*}{ 前 } & \multirow[t]{2}{*}{7} & 目 \\
\hline & & & & & 增減率(\%) \\
\hline $\begin{array}{l}\text { 無 } \\
\text { 処 } \\
\text { 罱 }\end{array}$ & $\begin{array}{c}4 \\
\text { 例 }\end{array}$ & 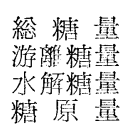 & $\begin{array}{r}4099 \pm 443 \\
1113 \pm 117 \\
949 \pm 55 \\
2037 \pm 324\end{array}$ & $\begin{array}{r}3720 \pm 368 \\
992 \pm 81 \\
939 \pm 115 \\
1789 \pm 310\end{array}$ & $\begin{array}{l}-9.2 \pm 4.0 \\
-12.8 \pm 9.0 \\
-1.1 \pm 6.8 \\
-12.2 \pm 5.2\end{array}$ \\
\hline 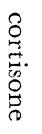 & 例 & 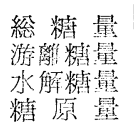 & $\begin{array}{r}4952 \pm 466 \\
1169 \pm 90 \\
885 \pm 128 \\
2898 \pm 189\end{array}$ & $\begin{array}{r}6261 \pm 515 \\
1134 \pm 145 \\
771 \pm 38 \\
4356 \pm 597\end{array}$ & $\begin{array}{l}+26.4 \pm 13.1 \\
-3 . \pm 12.1 \\
-12.9 \pm 8.6 \\
+50.3 \pm 14.5\end{array}$ \\
\hline $\begin{array}{l}\wp \\
\wp \\
\triangleright\end{array}$ & $\begin{array}{c}3 \\
\text { 例 }\end{array}$ & 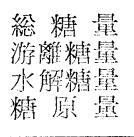 & $\begin{array}{r}4910 \pm 437 \\
1060 \pm 72 \\
882 \pm 54 \\
2968 \pm 375\end{array}$ & $\begin{array}{l}4469 \pm 474 \\
1053 \pm 53 \\
1054 \pm 43 \\
2362 \pm 510\end{array}$ & $\begin{array}{r}-9.0 \pm 3.8 \\
-0.7 \pm 11.8 \\
+19.5 \pm 2.4 \\
-20.4 \pm 7.3\end{array}$ \\
\hline 茎 & $\begin{array}{l}3 \\
\text { 例 }\end{array}$ & 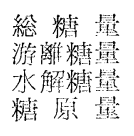 & $\begin{array}{r}3024 \pm 271 \\
889 \pm 171 \\
674 \pm 205 \\
1461 \pm 761\end{array}$ & $\begin{array}{c}2278 \pm 248 \\
938 \pm 256 \\
426 \pm 16 \\
914 \pm 398\end{array}$ & $\begin{array}{l}-24.7 \pm 8.9 \\
+5.5 \pm 8.7 \\
-36.8 \pm 18.6 \\
-37.5 \pm 7.3\end{array}$ \\
\hline 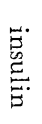 & $\begin{array}{l}3 \\
\text { 例 }\end{array}$ & 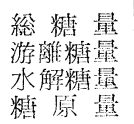 & $\begin{array}{r}2868 \pm 241 \\
1102 \pm 108 \\
737 \pm 41 \\
1029 \pm 218\end{array}$ & $\begin{array}{r}3350 \pm 210 \\
752 \pm 36 \\
878 \pm 35 \\
1720 \pm 258\end{array}$ & $\begin{array}{l}+16.8 \pm 3.2 \\
-31.8 \pm 3.5 \\
+19.1 \pm 2.0 \\
+67.2 \pm 15.8\end{array}$ \\
\hline
\end{tabular}

第7 表 無处箩， cortisone, DOCA, ACTH 及び insulin

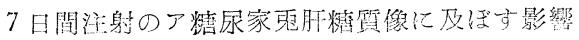
(精量は $\mathrm{mg}$ 向)

\begin{tabular}{|c|c|c|c|c|c|}
\hline \multirow{2}{*}{$\begin{array}{l}\text { 処 } \\
\frac{\mathrm{mc}}{1 ! 1} \\
\text { 別 }\end{array}$} & \multirow{2}{*}{$\begin{array}{l}\text { 例 } \\
\text { 数 }\end{array}$} & & \multirow{2}{*}{ 前 } & 7 & 目 \\
\hline & & & & & 増減率 $(\%)$ \\
\hline 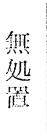 & $\begin{array}{c}5 \\
\text { 例 }\end{array}$ & 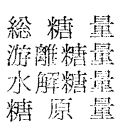 & $\begin{array}{r}2025 \pm 148 \\
757 \pm 99 \\
587 \pm 31 \\
681 \pm 141\end{array}$ & $\begin{array}{r}1758 \pm 124 \\
713 \pm 130 \\
568 \pm 105 \\
477 \pm 104\end{array}$ & $\begin{array}{l}-13.2 \pm 4.9 \\
-5.8 \pm 12.3 \\
-3.2 \pm 7.3 \\
-30 . \pm 6.1\end{array}$ \\
\hline 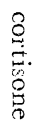 & $\begin{array}{c}4 \\
\text { 例 }\end{array}$ & 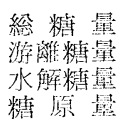 & $\begin{array}{r}1474 \pm 178 \\
449 \pm 66 \\
500 \pm 28 \\
525 \pm 145\end{array}$ & $\begin{array}{r}1884 \pm 148 \\
678 \pm 115 \\
645 \pm 45 \\
561 \pm 17\end{array}$ & $\begin{array}{l}+27.7 \pm 11.3 \\
+51 . \pm 16.3 \\
+29 . \pm 16.3 \\
+6.9 \pm 28.6\end{array}$ \\
\hline $\begin{array}{l}\forall \\
\varnothing \\
\supset\end{array}$ & 例 & 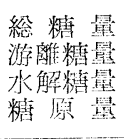 & $\begin{array}{r}1405 \pm 188 \\
626 \pm 181 \\
450 \pm 78 \\
329 \pm 56\end{array}$ & $\begin{array}{r}1195 \pm 202 \\
596 \pm 61 \\
382 \pm 94 \\
217 \pm 47\end{array}$ & $\begin{array}{l}-14.9 \pm 3.8 \\
-4.8 \pm 18.1 \\
-15.1 \pm 2.8 \\
-3.6 \pm 17.2\end{array}$ \\
\hline $\begin{array}{l}\text { 足 } \\
\text { 㝵 }\end{array}$ & 例 & 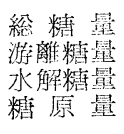 & $\begin{array}{r}1672 \pm 165 \\
627 \pm 105 \\
543 \pm 16 \\
502 \pm 158\end{array}$ & $\begin{array}{r}1466 \pm 191 \\
535 \pm 102 \\
509 \pm 57 \\
422 \pm 161\end{array}$ & $\begin{array}{l}-12.3 \pm 4.8 \\
-14.7 \pm 14.0 \\
-6.3 \pm 8.2 \\
-15.9 \pm 7.8\end{array}$ \\
\hline 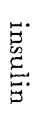 & 例 & 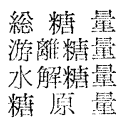 & $\begin{array}{r}1460 \pm 217 \\
601 \pm 83 \\
498 \pm 75 \\
361 \pm 46\end{array}$ & $\begin{array}{r}1399 \pm 183 \\
460 \pm 54 \\
590 \pm 9 \\
349 \pm 23\end{array}$ & $\begin{array}{l}-4.2 \pm 2.2 \\
-23.5 \pm 1.7 \\
+18.5+16.5 \\
-3.3 \pm 7.0\end{array}$ \\
\hline
\end{tabular}

ら，両埸合に於ける降血糖作用は本筫的 に゙相造していることが䇲える゙卵ち， insulin では臟器，組織に於ける糖貿增 加により，又 DOGA でば專ら未梢飞於 ける糖消費旺盛若くは糖加ら脂肪への転 化昰盛により降血糖它見たものと推せら れ，DOCA の精質代謝に対する作用は むしろ guanidine 様作用である様に見 受けられる。

[B] 正常蕜びに alloxan 糖尿家鬼に 於ける下梨体劃監皮監系ホルモン長期間 注的後の䀒糖質像変化

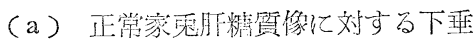

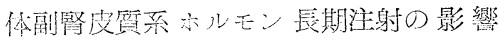
(筑 6 偎)

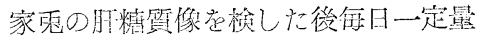
の本系ホルモン若くは insulin 学7 日同

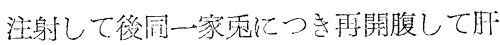

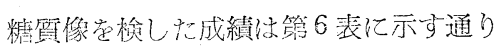
でる.

総糖質量讨 cortisone $\zeta$ insulin より增加, DOCA 前びそ ACTH によ り減少を見ている。

各個糖質像では cortisone $と$ insulin そよつて糖愿蠠の著明な增加を，又 DOCA 並びに ACTH 亿依つては糖原 最の減少总証せられた。

其の他各個糖質像要化では insulin よつて你肝游漓糖の減少か稍々著明であ つて，其の為に肝糖原缢で insulin よつて著增危見たが肺総糖質量では軽増 觉たにすざなかつた。

(b) alloxan 糖永家鬼肝糖質像に対 する下垂体副篎皮䁈系ホルモン長期間注 射 $\sigma$ 影響 (符 7 表)

alloxan 糖尿家鬼でも正常家鬼の場合 と略々同様な結果であつて総糖質基俉 cortisone 飞よつて稍々著增, insulin に よつて壡增, DOCA 並びに ACTH に 依つては好照と比較して翏化觉胃なかつ た。糖原嚳は cortisone で增加を, DOCA 並びに insulin そよつては微減

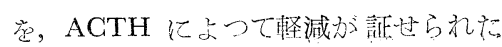


第 8 表 肝切片摘出手術(刘䳟)及び各種ホルモン 7 日間注射の正常並びにアロキサン粘展

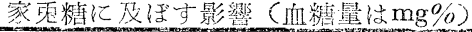

\begin{tabular}{|c|c|c|c|c|c|}
\hline & \multirow{2}{*}{ 処置 別 } & \multirow{2}{*}{$\begin{array}{l}\text { 例 } \\
\text { 数 }\end{array}$} & \multirow{2}{*}{ 前 } & 7 & 日 \\
\hline & & & & & 堌減寀 $(\%)$ \\
\hline \multirow{5}{*}{$\begin{array}{l}\text { 正 } \\
\text { 常 } \\
\text { 家 } \\
\text { 死 }\end{array}$} & 対 & 4 & $101 \pm 4$ & $99 \pm 1$ & $-2 . \pm 2.6$ \\
\hline & cortisone & 3 & $118 \pm 6$ & $115 \pm 2$ & $-2.5 \pm 6.5$ \\
\hline & DOCA & 3 & $119 \pm 3$ & $108 \pm 1$ & $-9.2 \pm 2.4$ \\
\hline & ACTH & 3 & $101 \pm 11$ & $112 \pm 20$ & $+10.9 \pm 7.4$ \\
\hline & insulin & 3 & $103 \pm 7$ & $100 \pm 3$ & $-2.9 \pm 9.1$ \\
\hline \multirow{5}{*}{$\begin{array}{l}\text { ア } \\
\text { 粧 } \\
\text { 尿 } \\
\text { 家 } \\
\text { 霓 }\end{array}$} & 缺 & 5 & $262 \pm 24$ & $268 \pm 21$ & $+2.3 \pm 7.3$ \\
\hline & cortisone & 4 & $276 \pm 4$ & $300 \pm 31$ & $+8.7 \pm 9.7$ \\
\hline & DOGA & 3 & $260 \pm 58$ & $255 \pm 49$ & $-1.9 \pm 12.6$ \\
\hline & ACTH & 4 & $320 \pm 19$ & $310 \pm 9$ & $-3.1 \pm 4.3$ \\
\hline & insulin & 3 & $320 \pm 26$ & $291 \pm 22$ & $-9.1 \pm 14.4$ \\
\hline
\end{tabular}

が，其の何れも刘照 alloxan 家鬼に於 ける7日間経過中亿於ける減少度と比較

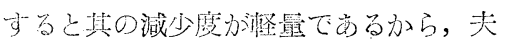
等のホルモンに依つて肝糖原舅は堌加の 万向作用咕られたと観得られる。

要するに正管家鬼でも alloxan 糖尿 家鬼でも同様に其の長期間注射䒠験では

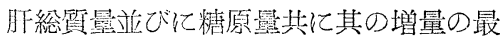
大であつたのは cortisone 注射家鬼であ つて次飞 insulin 注射家鬼が位し， DOCA とACTH によつては肝糖原量 蚛正消家鬼では減少，alloxan 糖尿家鬼 では腈增力証造られていて，要するに此

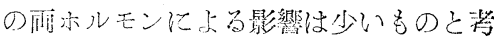
えられ\%。

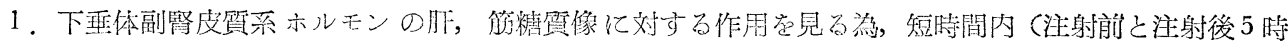

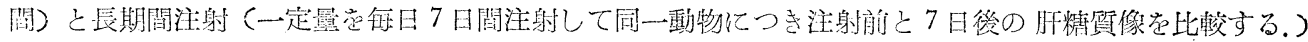

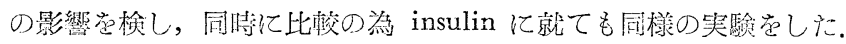

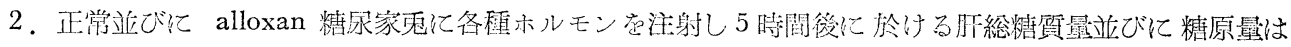
DOCA 注射家鬼では其の減少か潲々落暊であつた。 cortisone 及び ACTH 注射家鬼では正常並びに all一

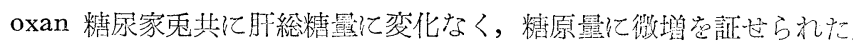

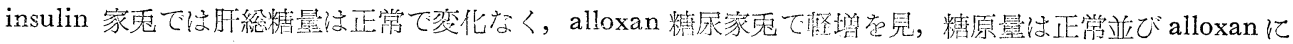
糖尿家鬼共㦈加党見た。

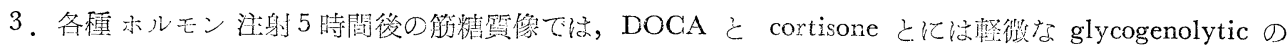

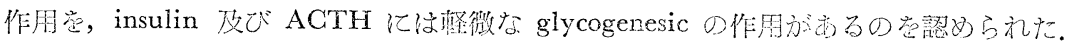

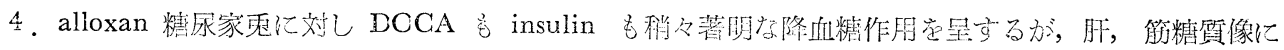

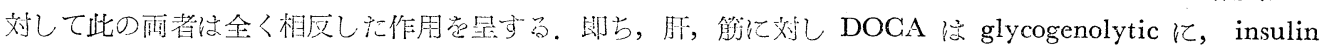

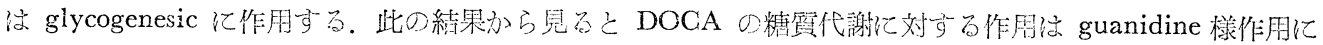
類するとと見受けられた。

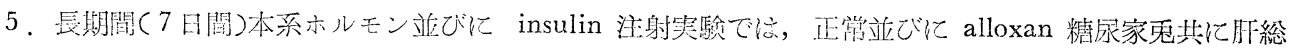

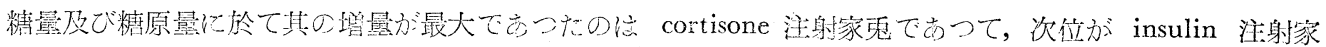
乘であつた。

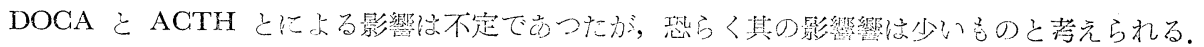

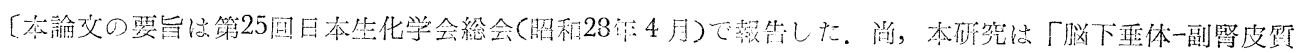

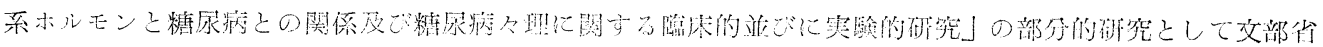

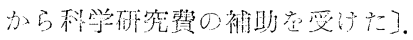

\section{参考妾 䘞}

1) Houssay \& Potick: Compt. rend. soc. de. Biol. 101, 940, 1929.

J. physiol. 134, 8, 1941. 誌， 31, 645, 1956.
3) 藤田：日内全点，43，581，1954.

5) 楃山：日本队分泌学会誌，35，26，1955.
2) Grattan, Jensen \& Ingle : Am.

4) 喜田:日本内分泌学会 6) 中野等：日内全諰， 
$3,44,1955$.

7) Britton \& Silvette : Am. J. physiol. 100. 701, 693, 1932.

8) Thaddea :

Ztschr. ges. exper. Med. 95, 600, 1935.

9) Kerppola: Endocrin. 51, 192, 1952.

10) Long,

Katzin \& Fry: Endocrin. 26, 600, 1935.

11) Dorfman, Ross \& Shipley: Endocrin. 38, 178, 1946.

12) Verrning, Kazmin \& Bell: Endocrin. 38, 79, 1946.

13) Eggleston, Johnston \& Dobriner : Endocrin. 38, 197, 1946.

14) Grattan \&Jensen: Am. J. physiol. 134, 8, 1941.

15) Kortsàk,

Wang \& Verzàr: Am. J. physiol. 159, 263, 1949.

16) Ingle: Endocrin. 27, 297, 1940.

17)

Long, Ketzin \& Fry: Endocrin. 26, 309, 1940.

18) Russell \& Bennetf : Proc. Soc. exper. Biol. \&

Med. 34, 406, 1936.

19) Bennett : Am. J. physiol. 150, 400, 1947.

20) Bennett \& Perkins :

Endocrin. 36, 24, 1947.

21) Russell \& Willhelmi: J. Biol. Chem. 137, 713, 1941.

22)

Milman \& Russell : Proc. Soc. Enper. Biol. \& Med. 76, 510, 1950.

23) Long, Katzin \& Fry:

Endocrin. 26, 309, 1940.

24) Engel, Schiller \& Pentz : Endocrin. 39, 293, 1946.

25)

Engel: Rerent Prog. Hormone. Res. 6, 277, 1951.

26) 山本: J. Biochem. 32, 289, 1940.

27)

Hagedorn \& Jensen: Biochem. Z. 135, 469, 1923. 